fact, one of the declared purposes of the postgraduate scholarship scheme of the New Zealand University Grants Committee.

\section{In the Steps of Rutherford}

THE New Zealand National Research Advisory Council's estimates for expenditure on scientific research slowly increase, both absolutely and as a percentage of the gross national product. The estimate for 1966-67 is just over $£ 10$ million or 0.5 per cent of the gross national product. When this is compared with the British figure of about $2 \cdot 6$ per cent of the gross national product or the American figure of about 3 per cent, it is perhaps not surprising that New Zealand loses such a large percentage of first class graduates in the brain drain. The Council recommends that the Government should return to its support of the policy the Council originally set out in its first annual report, that of a steady and deliberate growth in the research effort with growth rates ccncentrated in those areas of research most likely to prove beneficial to the country's economy.

The Council recommends the expansion of the laboratory building programme if present urgent needs are to be met and if expansion of certain research is to be carried out. It points out that accommodation is already overcrowded and that, although it is estimated that the building requirements for the Department of Scientific and Industrial Research would involve £5 million over the next five years (excluding the cost of land), the annual expenditure over the past two years for land and building for scientific purposes for all Government Departments has amounted to only $£ 0 \cdot 5$ million.

The chief new recommendation of the Council is that a programme of ecological research should be implemented by the Government. Less than one-third of New Zealand is intensively farmed and a large proportion of the remainder is composed of forest and country tussock grassland, forming important water catchment areas. Problems of soil erosion which might lead to flooding have pointed the way to urgent changes in the basis of land usage. Recently there has been a realization that water resources, long regarded as unlimited, need prudent management.

\section{Discussing Proteins}

THE Chemical Society has found enthusiasm for its proposal to form a Protein Group. The idea is to bring together scientists from different disciplines who share an interest in proteins and peptides. Discussion would cover the synthesis, structure, physical properties and biological activity of proteins, and organization of the meetings would be provided by the Chemical Society. Dr G. T. Young, of the Dyson Perrins Laboratory at Oxford, to whom interested scientists have been asked to write, reports an encouraging response-about 50 have replied approving the idea. Membership of the group would not be confined to members of the Chemical Society, but in order to get it started it is necessary to provide evidence that at least 25 fellows are interested. The idea can then be put forward to the Council of the Chemical Society.

The next step will be to organize an inaugural meeting, some time before the end of the year. This would probably be a scientific meeting, to encourage as many as possible to come. It would also be necessary to elect a committee, but Dr Young modestly declares that he has no ambitions in this direction. $\mathrm{He}$ is hoping that the group will attract the younger workers, and that they will be prepared to run it. "We don't want the same old people giving the same old papers," he says.

\section{Extending Photography}

THE year 1967 could be a vintage year for the Loch Ness monster. Earlier this year it was announced that the Highland and Islands Development Board had given a grant of $£ 1,000$ to a "Monster" study group, headed by Mr David James, and on July 20 Kodak Ltd. announced that it was giving $£ 1,230$ to an insurance underwriter, Mr T. K. Dinsdale, to carry out his own studies into the phenomenon. This sudden largesse in the direction of $\mathrm{Mr}$ Dinsdale is all part of the Kodak Awards for 1967-68. The purpose of these awards is to stimulate original thought on problems relating to the photographic process and to extend the use of photography into other fields. Kodak has made seventeen awards this year totalling $£ 9,433$. The research supported ranges from Mr Dinsdale's project to medical photography, and includes a large number of studies of audio-visual aids in teaching.

Another project is that of Dr W. Hartson, who is studying techniques for producing photomicrographs of the smallest blood vessels in normal and diseased skin using intense infra-red light and infra-red sensitive film. Mr C. C. Gilson, a medical photographer, will investigate various methods of making contour maps of the human cornea using interferometry. His purpose is to detect damage to the cornea caused by wearing contact lenses; the established method, called keratography, is apparently not sufficiently accurate.

The awards are given to individuals rather than institutes. They are given not only to professional researchers but also to people such as schoolteachers who wish to study the uses of photography in their vocation.

\section{Radiation and the Immune Response}

\section{from a Correspondent}

RADIATION and the control of the immune response was the topic discussed at a meeting organized by the International Atomic Energy Agency and the French Atomic Energy Commission, which was held in June this year at the Fondation Curie in Paris.

The nineteen delegates heard persuasive evidence for a radiosensitive antigen-processing step inside macrophages which might play a significant part in the immune response. Immunological tolerance can be induced in newborn rats by extremely low doses of salmonella flagellin antigen which, when labelled, cannot be detected by electron microscopy. Thus, the determination of a tolerance-inducing threshold for purified histo-compatibility antigens in man may be a practical proposition.

A suggestion that in the evolution of the immune response the antibodies appear in the sequence IgM, IgA, IgG contrasted with the evidence for the affinity of antibodies for monovalent haptenes, which is in the reverse order. Memory was excellent for IgG, but less impressive for IgM and IgA. Evidence seems to sug- 